(C) О.Л. Фучко, 2019

УДК 616-092:616.3+616.4

\title{
Особливості тиреоїдного статусу у жінок із гіперплазісю щитоподібної залози, поєднаною з безкалькульозним холециститом
}

\author{
О.Л. Фучко
}

Ужгородський національний університет, кафедра фізіології та патофізіології, Ужгород

\section{Реферат}

Проведено комплексне обстеження 87 жінок віком 22-54 роки, у яких хронічний безкалькульозний холецистит був основним діагнозом, а гіперплазія щитоподібної залози вперше встановлена в умовах курорту Трускавець, і відповідно ці жінки не застосовували препаратів для ії лікування. Встановлено, що за наявності гіперплазії щитоподібної залози та безкалькульозного холециститу тиреоїдний статус у жінок характеризується ознаками гіпофункції щитоподібної залози, і зміни у іiї функції відбуваються за типом гіпотиреозу. Тиреоїдний статус у таких пацієнтокв за деякими ознаками відповідає субклінічному, за деякими - маніфестному первинному гіпотиреозу на додаток із синдромом "низького $\mathrm{T}_{3}$ ". Величини показників, що характеризують гормональний статус обстежених, у чистому вигляді не відповідають притаманним жодному із зазначених патологічних станів.

Ключові слова: безкалькульозний холецистит, гіперплазія щитоподібної залози, тиреоїдний статус, гіпотиреоз.

Features of thyroid status in women under hyperplasia of the thyroid gland, combined with noncalculous cholecystitis O.L. Fuchko

Uzhhorod National University, Department of Physiology and Pathophysiology, Uzhhorod

\section{Abstract}

It was conducted a comprehensive survey of 87 women aged 22-54 years who had chronic noncalculous cholecystitis as the main diagnosis, and hyperplasia of the thyroid gland was firstly established in the conditions of the resort Truskavets, and accordingly, these women did not use drugs for its treatment. It was found that in the presence of thyroid gland hyperplasia and noncalculous cholecystitis, thyroid status in women is characterized by hypofunction of the thyroid gland, and changes in it functioning occur by the type of hypothyroidism. The thyroid status of such patients, according to some features, corresponds to subclinical, in some cases - manifest primary hypothyroidism in addition with the syndrome of "low $\mathrm{T}_{3}$ ". The values of the parameters that characterize the hormonal status of the patients, in its pure form not meet any of these pathological conditions.

Key words: noncalculous cholecystitis, thyroid gland hyperplasia, thyroid status, hypothyroidism.

Вступ. Гіперплазія щитоподібної залози є на теперішній час поширеною патологією. Причому вважають, що захворювання щитоподібної залози часто поєднуються з патологією печінки, причому порушення функцій щитоподібної залози можуть призводити до змін функцій печінки, а за наявності захворювань печінки можуть виникати відхилення у метаболізмі тиреоїдних гормонів $[5,15,19]$.

При структурних змінах залози спостерігаються різні типи порушення гормонального статусу організму - від гіпертиреозу через еутиреоз до гіпотериозу. Тобто наявність гіперплазії не $\epsilon$ показником того, за яким типом буде відбуватися перебіг захворювання, обумовленого патологією щитоподібної залози [14,21]. Ще більшою мірою таке твердження є справедливим у тому випадку, коли до порушень функціонування щитоподібної залози додається супутня патологія, у тому числі, захворювання печінки та жовчного міхура. Останнє пов'язане з тим, що значну роль у печінковому гомеостазі ліпідів відіграють тиреоїдні гормони. Також печінка виконує специфічні функції, пов'язані 3 транспортом i метаболізмом тиреоїдних гормонів - у печінці синтезується ряд плазматичних білків, котрі зв'язують ліпофільні тиреоїдні гормони, в результаті чого в циркуля- торному руслі формується великий пул гормонів, що швидко обмінюється. Тобто реалізація ефектів тиреоїдних гормонів напряму залежить від функцій печінки. Отже, зміни, які відбуваються в функції щитоподібної залози, є обопільно обумовленими $з$ функціонуванням печінки, і існує низка патогенетичних процесів, при яких тиреоїдні гормони одночасно впливають і на щитоподібну залозу і на печінку. До таких належать, наприклад, мультисистемні аутоімунні порушення на кшталт аутоімунних захворювань щитоподібної залози, що розвиваються при хронічному гепатиті. 3 іншого боку, при захворюваннях щитоподібної залози часто порушується функція печінки. Причому ці порушення залежать від того, за яким типом відбуваються зміни тиреоїдної функції залози, тобто спостерігається гіпо- або гіпертиреоз [20,21]. При різних формах захворювань печінки можуть виникати зсуви, подібні до таких при синдромі еутиреоїдної патологї [22,23]. Дослідники підкреслюють складність оцінки того, які характеристики, що мають місце при захворюваннях печінки, безпосередньо пов'язані з тиреоїдним статусом.

Найпоширенішим захворюванням печінки i, взагалі, одним $з$ найпоширеніших захворювань у світі є холецистит. Холецистит відносять до холестатичних порушень, що можуть бути пов'язаними 
зі змінами тиреоїдного статусу, тобто зі зміною функції щитоподібної залози [9]. Обидва ці порушення вимагають патогенетично обгрунтованого лікування, спрямованого, у першу чергу, на нормалізацію нейрогуморального гомеостазу організму хворих.

Незважаючи на наявність значної кількості робіт, присвячених подібним проблемам, на основі отриманих до теперішнього часу даних важко скласти повну і всебічну картину взаємозв'язку та взаємовпливу метаболічних процесів, які відбуваються в щитоподібної залозі та печінці $[1,2,6,12]$. Така складність обумовлюється мультифакторністю механізмів, котрі відповідають за фізіологічну функцію, а також розвиток та перебіг патологічних станів у даних органах, що вимагає поглиблених досліджень для формування чіткої патофізіологічно обгрунтованої концепції.

Мета дослідження. Виявити особливості тиреоїдного статусу у жінок 3 гіперплазією щитоподібної залози, поєднаною з безкалькульозним холециститом.

Матеріали та методи. Для досягнення поставленої мети було відібрано 87 жінок віком 22-54 роки, у яких хронічний безкалькульозний холецистит виступав як основний діагноз, а гіперплазія щитоподібної залози була вперше встановлена в ході обстеження в умовах курорту Трускавець, i відповідно ці жінки не застосовували препаратів для iі лікування (основна група). Наявність гіперплазії верифікували методом ехоскопії за допомогою ехокамер «Sonoline Elegra» (Німеччина) та «Acuson-128 XР/10» (США). Контрольну групу, рандомізовану за віком, склали 20 здорових жінок.

Із метою уникнення можливих значних коливань гормонального статусу обстеження в контрольній групі та групі жінок із патологією починали у перші дні оваріально-менструального циклу.

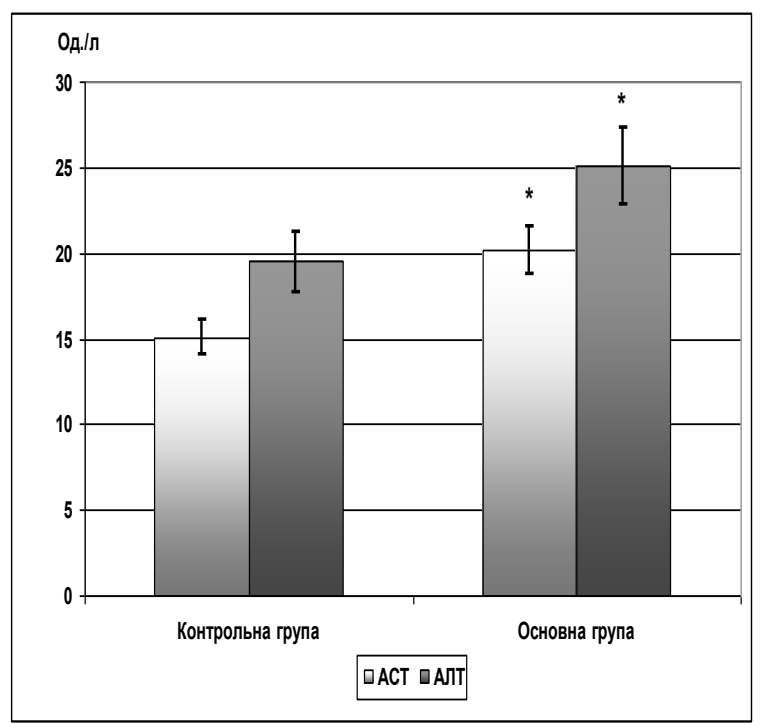

Для визначення активності аланінамінотрансферази (АЛТ) і аспартатамінотрансферази (АСТ) використовувався колориметричний метод $[8,18]$.

Гормональний статус оцінювали за вмістом в плазмі крові тиреоїдних гормонів, який визначали методом твердофазного імуноферментного аналізу 3 використанням відповідних наборів реагентів ЗАТ «Алкор Био» (РФ) та аналізатора «Тесап» (Німеччина).

Вільні тироксин (fT 4 ) та трийодтиронін ( $\mathrm{fT}_{3}$ ) визначали за допомогою конкурентного імуноферментного аналізу - аналогового методу для вільного $\mathrm{T}_{3} \mathrm{i} \mathrm{T}_{4}$ [13]. Концентрацію тироглобуліну (TG) в сироватці крові визначали за допомогою радіоімунологічного методу із застосуванням подвійних антитіл [10] [Инструкции ЗАО «Алкор Био», 2000; Павлов А.В. и др., 2006]. Вміст тиреотропного гормону (ТТГ) визначали за реакцією зв'язування 3 анти-ТТГ моноклональними антитілами $[7,13]$.

Статистична обробка отриманих даних проведена методами варіаційної статистики 3 вирахуванням середньої арифметичної, іï середньої похибки, а також критерію достовірності Стьюдента за допомогою програмного забезпечення Microsoft Excel 2003. Відмінності вважались вірогідними при $\mathrm{p}<0,05$.

Результати досліджень та їх обговорення. Для верифікації наявності і вираженості патології печінки та iï функціонального стану в обстежуваних пацієнток із гіперплазією щитоподібної залози проведено дослідження вмісту ферментів аспартатамінотрансферази та аланінамінотрансферази. Оцінювали також величину коефіцієнту Ритіса - співвідношення АСТ/АЛТ. Виявлено, що у пацієнток показники АСТ та АЛТ були достовірно підвищеними відносно контрольної групи (рис. 1).

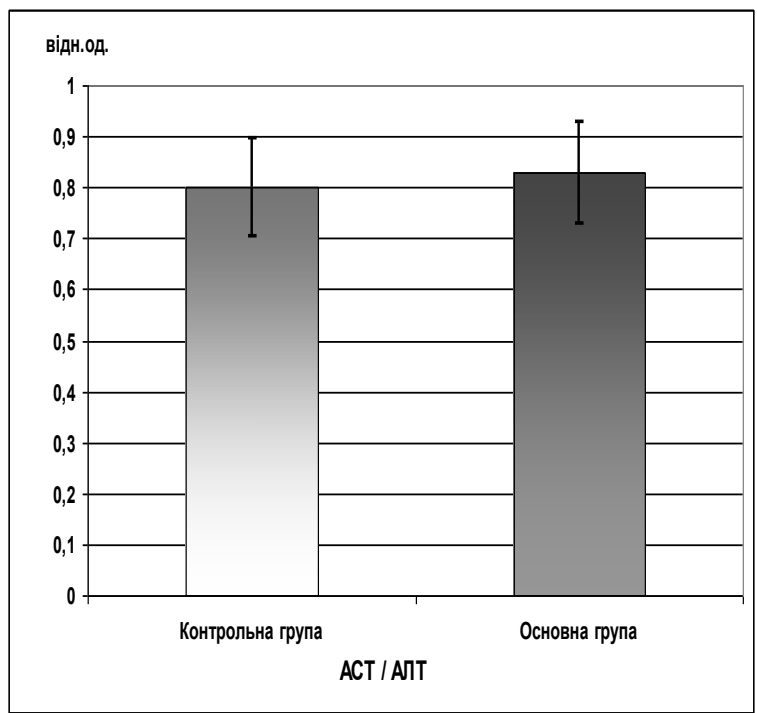

Рис. 1. Зміни активності АСТ, АЛТ та коефіцієнта Ритіса в крові жінок із безкалькульозним холециститом та наявністю гіперплазії щитоподібної залози.

* - різниця з контролем достовірна $(\mathrm{p}<0,05)$. 
Можна також припустити наявність вже і деструктивних змін печінкової клітини при досить вираженому зростанні величин досліджуваних показників (АСТ - на 33,9\% та АЛТ - на 28,6\%), що $є$ цілком імовірним при хронічному процесі в печінці, вказує на зниження детоксикаційної здатності печінки, і може ускладнювати перебіг гіперплазії щитоподібної залози. Окрім цього, підвищення активності АЛТ та/або АСТ в плазмі крові може супроводжувати не тільки пошкодження печінки, але й у 40-90 \% випадків спостерігається при гіпотиреозі [3].

Підтвердженням наявності печінкової патології вважають також зниження коефіцієнта Ритіса більше, ніж на 30\%. Оцінка співвідношення АСТ/АЛТ у обстежених жінок виявила, що достовірних його змін порівняно 3 контрольними рівнями не спостерігалося: в контрольній групі означений коефіцієнт дорівнював $0,80 \pm 0,22$, в групі хворих - 0,83 $\pm 0,14$ (див. рис. 1). Такий результат вказує на відсутність тяжкого ураження печінки, i може бути свідченням того, що пацієнтки перебували в стадії досить стійкої ремісії.

Проведені обстеження виявили суттєві зміни тиреоїдного статусу у жінок з гіперплазією щитоподібної залози, хворих на холецистит (табл. 1).

Таблиця 1

Концентрації тиреоїдних гормонів у крові жінок з гіперплазією щитоподібної залози та безкалькульозним холециститом $(\mathrm{M} \pm \mathrm{m}, \mathrm{n}=87)$

\begin{tabular}{|l|c|c|}
\hline \multicolumn{1}{|c|}{ Показники } & Контрольна група & Основна група \\
\hline $\begin{array}{l}\text { Зв'язаний трийодтиронін }\left(\mathrm{T}_{3}\right), \\
\text { нМ/л }\end{array}$ & $2,10 \pm 0,09$ & $1,55 \pm 0,17^{*}$ \\
\hline $\begin{array}{l}\text { Вільний трийодтиронін }\left(\mathrm{fT}_{3}\right), \\
\text { пМ/л }\end{array}$ & $6,5 \pm 0,2$ & $6,4 \pm 0,2$ \\
\hline Зв’язаний тироксин $\left(\mathrm{T}_{4}\right), \mathrm{HM} /$ л & $110 \pm 4$ & $98 \pm 8$ \\
\hline Вільний тироксин $\left(\mathrm{fT}_{4}\right)$, пМ/л & $18,0 \pm 0,7$ & $14,0 \pm 0,8^{*}$ \\
\hline $\begin{array}{l}\text { Тиреотропний гормон (ТТГ), } \\
\text { мМО/л }\end{array}$ & $1,90 \pm 0,30$ & $4,30 \pm 0,70^{*}$ \\
\hline Тироглобулін (ТG), мкг/л & $30 \pm 3$ & $71 \pm 15^{*}$ \\
\hline
\end{tabular}

Примітка: * - різниця достовірна з показниками контрольної групи $(\mathrm{p}<0,05)$

Зважаючи на значну різноспрямованість можливих змін концентрацій тиреоїдних гормонів в крові при гіперплазії щитоподібної залози, перш ніж оцінити тиреоїдний статус жінок, обстежених в ході досліджень, слід звернути увагу на сучасну класифікацію цього статусу, розроблену на основі даних Американської тиреоїдологічної асоціації: 1) якщо ТТГ є зниженим, а $T_{3}$ - підвищеним - це вказує на ознаки гіпертиреозу; 2) якщо ТТГ є зниженим, а $\mathrm{T}_{3}$ не відрізняється від належних величин - це вказує на ознаки субклінічного гіпертиреозу або еутиреозу; 3) якщо ТТГ і $\mathrm{T}_{3}$ не відрізняються від належних величин - це вказує на ознаки еутиреозу; 4) якщо ТТГ є підвищеним, а $\mathrm{T}_{3}$ та $\mathrm{T}_{4}-$ зниженими - це вказує на ознаки гіпотиреозу; 5) якщо ТТГ $\epsilon$ підвищеним, а $\mathrm{T}_{3}$ та $\mathrm{T}_{4}-$ зниженими або такими, що не відрізняються від належних величин - це вказує на ознаки субклінічного гіпотиреозу [24].

Дані, наведені в таблиці, свідчать про те, що у хворих спостерігали суттєве (у 2,26 разу) зростання відносно контрольних величин рівня ТТГ. Поряд 3 цим концентрація $\mathrm{T}_{3}$ виявлялася достовірно (на $35,5 \% ; \mathrm{p}<0,05$ ) зниженою, а концентрація $\mathrm{T}_{4}$ була достовірно не зміненою $(\mathrm{p}>0,05)$. Тобто при аналізі середніх даних ТТГ та $\mathrm{T}_{4}$ по групі обстежених жінок та порівнянні з наведеною вище класифікацією можна дійти до висновку про те, що гіперплазія щитоподібної залози на тлі безкалькульозного холециститу супроводжується ознаками первинного субклінічного гіпотиреозу.

Проте, якщо проаналізувати зміни ТТГ та $\mathrm{fT}_{4}$, однозначність такого висновку може піддаватися сумніву. Дослідниками показано, що між рівнями ТТГ i $\mathrm{T}_{4} \epsilon$ логарифмічна залежність, у зв'язку 3 чим навіть невелике зниження концентрації вільного $\mathrm{T}_{4}$ трансформується в значно вираженіше збільшення рівня ТТГ. Таким чином, субклінічний гіпотиреоз визначається тоді, коли рівень вільного $\mathrm{T}_{4}$ формально знаходиться в межах норми. У випадку обстежених нами пацієнтів концентрація вільного $\mathrm{T}_{4} \epsilon$ достовірно (на $28,6 \%, \mathrm{p}<0,05$ ) зниженою (див. табл. 1). Таку динаміку прийнято розглядати як маніфестний первинний гіпотиреоз $[6,17]$.

Однак слід прийняти до уваги, що у обстежених жінок визначено достовірно знижений рівень $\mathrm{T}_{3}$. Вважається, що для діагностики гіпотиреозу оцінка $\mathrm{T}_{3}$ не $\epsilon$ необхідною. У типових ситуаціях цей показник змінюється односпрямовано $3 \mathrm{~T}_{4}$, хоча нерідкісні випадки, коли $\mathrm{T}_{3}$ тривало залишається нормальним при вже пониженому $\mathrm{T}_{4}$ [24]. Останній феномен пояснюється підвищенням активності тканинної 5'-дейодінази, метаболізм якої, у тому числі, пов'язаний 3 активністю метаболічних процесів у печінці $[11,5]$. При цьому 
особливості тиреоїдного статусу при гіпотиреозі необхідно диференціювати від синдрому "низького $\mathrm{T}_{3}{ }^{\prime \prime}$ [23]. При соматичних захворюваннях, наприклад, нирковій, серцевій, печінковій недостатності порушується активність периферичної 5'дейодінази, що виявляється зниженням загального та/або вільного $\mathrm{T}_{3}$, при нормальному або підвищеному рівні $\mathrm{T}_{4}$ i часто нормальному ТТГ. Тобто наявність печінкової патології може призводити до зниження $\mathrm{T}_{3}$. Останнє унеможливлює віднести зміни тиреоїдного статусу обстежених пацієнток до якогось одного конкретного типу, передбаченого загальноприйнятою класифікацією [11].

У ході дослідження було виявлено значно (у 2,4 разу) збільшену концентрацію в крові хворих жінок тироглобуліну (див. табл. 1). Ця особливість може розглядатися, 3 одного боку, як додаткове свідчення наявності патологічного процесу у щитоподібній залозі, оскільки показано, що при деяких іiі захворюваннях (зоб, пухлини щитоподібної залози тощо) вивільнення тироглобуліну в кров підвищується і його концентрація може зростати більше, ніж у 2 рази (при нормі 16 мкг/л), тоді як у нормі лише незначна кількість тироглобуліну не піддається гідролізу і вивільняється 3 тироцитів одночасно з гормонами щитоподібної залози [16].

Якщо взяти до уваги процеси, у яких бере участь тироглобулін, виявлена у обстежуваних жінок динаміка змін його концентрації, до певної міри, може розглядатися як компенсаторна реакція. В результаті гідролізу тироглобуліну вивільняються $\mathrm{T}_{3} \mathrm{i} \mathrm{T}_{4} \mathrm{Ta}$, на додаток, вільні амінокислоти. Усі інгредієнти надходять в периваскулярний простір, а лізосомальні білки при цьому залишаються в клітині [4]. Паралельно відбувається вивільнення моно- та дийодтироніну, що піддаються дейодуванню під дією йодтирозиндейодази, котра виявляється в мітохондріях та мікросомах іє NADPH-залежним флавопротеїном. Вивільнений йодид знову використовується щитоподібною залозою в біосинтезі гормонів. Тому за умов наявності "низького $\mathrm{T}_{3}$ " та певних ознак гіпотиреозу підвищення концентрації тироглобуліну може сприяти обміну гормонів у щитоподібної залозі [15, 23].

Таким чином, отримані результати свідчать про те, що при гіперплазії щитоподібної залози поєднаної з безкалькульозним холециститом зміни тиреоїдного статусу мають своєрідний характер. Динаміка змін показників, що його характеризують, у чистому вигляді не відповідає притаманним або гіперплазії щитоподібної залози за гіпотиреозним типом, або безкалькульозному холециститу. Тиреоїдний статус за деякими ознаками відповідає субклінічному, за деякими - маніфестному первинному гіпотиреозу на додаток із синдромом "низького $\mathrm{T}_{3}$ ". Отже, за наявності гіперплазії щитоподібної залози поєднаної з безкалькульозним холециститом тиреоїдний статус характеризується ознаками ії гіпофункції.

Виявлені специфічні зміни гомеостатичних характеристик в організмі жінок з гіперплазією щитоподібної залози та безкалькульозним холециститом вимагають розробки нових ефективних підходів до лікування таких хворих.

Висновки. На основі отриманих результатів встановлено, що за наявності гіперплазії щитоподібної залози та безкалькульозного холециститу тиреоїдний статус у жінок характеризується ознаками гіпофункції щитоподібної залози, і зміни у іiі функції відбуваються за типом гіпотиреозу. Тиреоїдний статус у таких пацієнток за деякими ознаками відповідає субклінічному, за деякими маніфестному первинному гіпотиреозу на додаток 3 синдромом "низького $\mathrm{T}_{3}$ ". Величини показників, що характеризують гормональний статус обстежених, у чистому вигляді не відповідають притаманним жодному із зазначених патологічних станів.

Інформація про конфлікт інтересів. Автори заявляють про відсутність конфлікту інтересів при виконанні наукового дослідження та підготовці даної статті.

Інформація про фінансування. Автори гарантують, що вони не отримували жодних винагород у будь-якій формі, здатних вплинути на результати роботи.

\section{Список використаної літератури}

1. Adamova YaH, Chumachenko AN. Morfolohycheskye osobennosty razlychnoi patolohyy shchytovydnoi zhelezы u naselenyia, prozhyvaiushcheho $\mathrm{v}$ tekhnohenno-zahriaznennom rehyone. Arkhyv patolohyy. 2007;69(2)- 24-27. [In Russian].

2. Baskakov PN, Hlazkov YB. Korrektsyia dysmetabolycheskykh narushenyi u patsyentok s klymakterycheskym syndromom na fone zabolevanyi shchytovydnoi zhelezы y pecheny. Reproduktyvnoe zdorove zhenshchynы. 2005;1:42-43. [In Russian].

3. Braverman LY. Bolezny shchytovydnoi zhelezы. M.: Medytsyna. 2000. 256 c.

4. Borzyn VA, Herbylskyi LV, Kornylovskaia YN. Tyreohlobulyn. Problemы эndokrynolohyy. 1993;4:54-59. [In Russian].

5. Verbovoi AF. Syndrom hypotyreoza [Elektronnyi resurs]. Farmateka. 2015;10: http://www.medvestnik.ru/library/article/31601. [In Russian].

6. Vzaymosviaz mezhdu porazhenyiamy shchytovydnoi zhelezy y pecheny (obzor lyteraturы). - Rezhym dostupu: http://www.med-practic.com/rus/147/18796/Vzaymosviaz mezhdu porazhenyiamy shchytovydnoi zhelezы y pecheny/article.more.html. [In Russian]. 
7. Herasymov HA, Troshyna EA. Dyfferentsyalnaia dyahnostyka y vыbor metoda lechenyia pry uzlovom zobe. Problemы эndokrynolohyy. 1998;5:35-41. [In Russian].

8. Horiachkovskyi AM. Klynycheskaia byokhymyia. Odessa: Astroprynt. 1998. 608 s. [In Russian].

9. Zviahyntseva TD, Sharhorod YY. Khronycheskyi beskamennui kholetsystyt: klynyka, dyahnostyka y lechenye. Skhidnoievropeiskyi zhurnal vnutrishnoi ta simeinoi medytsyny. 2015;2:13-19. [In Russian].

10. Ymmunolohycheskaia dyahnostyka v akusherstve y hynekolohyy. NPP «mTm». $26 \mathrm{~s}$. [In Russian].

11. Proshchaev KY, Ylnytskyi AN, Kniazkyn YV, Kvetnoi YM. Molekuliarnaia neiroymmunoэndokrynolohyia y klynycheskaia patofyzyolohyia. SPb.: DEAN. 2006. 304 s. [In Russian].

12. Oleinyk VA. Hypotyreoz: patolohyia, o kotoroi vsehda nuzhno pomnyt. Ukrainskyi medychnyi visnyk. 2006;2:14-18. [In Russian].

13. Pavlov AV. Yspolzovanye mykroiadernoho testa dlia vыiavlenyia henotoksycheskykh povrezhdenyi shchytovydnoi zhelezы. Biulleten эksperymentalnoi byolohyy у medytsynы. 2006;141(1): 99-102. [In Russian].

14. Svyrydenko NIu, Kosianova NA. Hypotyreoz: dyahnostyka, pryntsypы zamestytelnoi terapyy. Russkyi medytsynskyi zhurnal. 2006;14(26): 1911-16. [In Russian].

15. Feisa SV. Patolohiia shchytopodibnoi zalozy ta nealkoholna zhyrova khvoroba pechinky. Ukraina. Zdorov'ia natsii. 2016;1-2: 198-202. [In Ukrainian].

16. Shakhtryn VV, Petrova HA, Chekyn SIu. Novыe podkhodы k kolychestvennoi otsenke metabolyzma tryiodtyronyna v orhanyzme. Problemы эndokrynolohyy. 2000;1: 34-37. [In Russian].

17. Kubarko AY, Yamasyta S.Shchytovydnaia zheleza. Fundamentalnыe aspektы. Mynsk-Nahasaky. 1998. 368 s. [In Russian].

18. Tytsa NU. Эntsyklopedyia klynycheskykh laboratornыkh testov. M.: Labynform. 1997. 942 s. [In Russian]. 19. Anty R, Lemoine M. Liver fibrogenesis and metabolic factors. Clin. Res. Hepatol. Gastroenterol. 2011;35(1):10-20.

20. Biondi B, Cooper DS. The clinical significance of subclinical thyroid dysfunction. Endocr. Rev. 2008;29:76131.

21. De Escobar HM. Autoimmune thyroid disease susceptibility Best Pract. Res. Clin. Endocrinal. 2004;19(2):311-15.

22. Duntas LH. Thyroid disease and lipids. Thyroid. 2002;12(2):287-93.

23. Iqbal A, Jorde R, Figenschau Y. Serum lipid levels in relation to serum thyroid-stimulating hormone and the effect of thyroxine treatment on serum lipid levels in subjects with subclinical hypothyroidism: the Tromso Study. J. Intern. Med. 2006; 260(1):53-61.

24. Bavab RCM, Derone D, Castro AVB, et al. Low triiodthyronine (T3) or reverse triodthyronine (rT3) syndrome modifies gene expression in rats with congestive heart failure. Endocr. Res. 2005;31(4):397-405.

25. Gharib H, Tuttle RM, Baskin HJ, et al. Subclinical thyroid dysfunction : a joint statement on management from the American Association of Clinical Endocrinologists, the American Thyroid Association, and The Endocrine Society. J. Clin. Endocrinol. Metabol. 2005; 90(1):581-85.

26. Tu HM. Regional distribushion of type 2 thyroxin deiodinase messenger ribonuk- leic acid in rat hypothalamus and pituitari and its regilation by thyroid hormone. M. Endocrinology. 1997;8:3359-68.

\section{Стаття надійшла до редакції: 12.03.2019 р.}

